\title{
Nitric oxide synthase inhibition and the uterotrophic response to oestrogen in immature rats
}

\author{
V. S. N. Rao, M. C. Chaves and R. A. Ribeiro \\ Departamento de Fisiologia e Farmacologia, Centro de Ciências da Saúde, Universidade Federal do Ceará, \\ Caixa Postal 3157, 60430-270, Fortaleza, Ce, Brazil
}

\begin{abstract}
The role of nitric oxide in the uterotrophic action of oestradiol after $6 \mathrm{~h}$ or $72 \mathrm{~h}$ was studied in immature (19-21 days old) female Wistar rats by use of L-arginine, the amino acid from which nitric oxide is synthesized, and $N^{\omega}$-nitro-L-arginine methyl ester (L-NAME), an inhibitor of nitric oxide synthase. Oestradiol at single s.c. doses of 2.5, 5.0 and $10.0 \mu \mathrm{g}$ per rat induced dose-dependent uterine oedema in $6 \mathrm{~h}$. L-NAME (10 and $20 \mathrm{mg} \mathrm{kg}^{-1}$, i.p.) administered $30 \mathrm{~min}$ before oestradiol (10 $\mu \mathrm{g}$ per rat) injection suppressed the formation of uterine oedema in a dose-related manner. This action of L-NAME on oestradiol-induced uterine oedema was effectively blocked by pretreatment of rats with L-arginine $(600 \mathrm{mg}$ $\mathrm{kg}^{-1}$, s.c.), a precursor of nitric oxide, but not by L-lysine, an amino acid not involved in the generation of nitric oxide. In addition, L-NAME at similar doses significantly prevented oestradiol-induced ( $3 \mu \mathrm{g}$ per rat, s.c. on three successive days) increases in uterine growth after $72 \mathrm{~h}$; however, this effect was mitigated by L-arginine $\left(600 \mathrm{mg} \mathrm{kg}^{-1}\right)$. These results suggest the involvement of an L-arginine-nitric oxide system in the oestradiol-induced uterotrophic effect in immature rats.
\end{abstract}

\section{Introduction}

Oestrogen induces a sustained increase in uterine blood flow, stromal oedema and epithelial proliferation (Makowski, 1977; Phaily and Senior, 1978; Magness and Rosenfeld, 1989). These effects arise from the interactions of oestrogen with a specific receptor protein in the uterine artery and in endometrial stromal cells (Tamaya et al., 1979; Cunha et al., 1983). However, the precise mechanism by which oestrogen brings about these changes in the uterus is not completely understood. Stromal oedema is probably dependent on a synergism between mediators that increase vascular permeability and mediators that enhance blood flow, whereas cellular hypertrophy is probably dependent on the synthesis and regulation of polypeptide growth factors. In this regard, numerous vasoactive substances, like adenosine, acetylcholine, bradykinin, histamine and prostaglandins (Resnick et al., 1976; Still and Greiss, 1978; Clark et al., 1981), and peptide growth factors, such as transforming growth factor- $\alpha$ / epidermal growth factor (TGF- $\alpha / E G F)$ and insulin-like growth factor I (IGF-I) (Murphy et al., 1987; Gardner et al., 1989; Nelson et al., 1992), have been implicated as the potential mediators because of their vasodilator or growth-promoting actions, but to date no specific antagonist has been able to inhibit or antagonize totally the uterotrophic action of oestrogen.

Yallampalli et al. (1994) hypothesized that an L-argininenitric oxide (NO)-cyclic guanosine monophosphate (cGMP)

Received 10 May 1995. system is present in the uterus and modulates uterine contractility and Van Buren et al. (1992) suggested that oestrogen could induce the available arginine to produce NO. Nitric oxide apparently stimulates soluble guanylate cyclase, increases the cellular concentration of cGMP and relaxes vascular smooth muscle (Ignarro et al., 1986). In addition, it appears to contribute to maintenance of basal vascular tone and to attenuate the actions of vasoconstrictors in fetal-placental circulation and regulate blood pressure during pregnancy (Myatt et al., 1992). Chronic inhibition of NO synthesis in pregnant rats can produce a pre-eclampsia-like syndrome in which there is sustained hypertension and intrauterine growth retardation (Molnar et al., 1994). These studies strongly suggest a vasoregulatory role for NO. Oestrogen is also vasoactive and is, therefore, available in high concentration during the follicular phase of the ovarian cycle and in pregnancy. Some of the vasodilatory substances produced and released under the influence of oestrogen, such as acetylcholine, histamine, angiotensin and bradykinin, were shown to induce or modulate endogenous NO (Moncada et al., 1991; Jovanovic et al., 1994). Therefore, it is plausible that the uterotrophic effect of oestrogen involves $\mathrm{NO}$.

Most of the biological assays for oestrogen are based upon the increased wet mass in immature or spayed rats (Calhoun et al., 1971). In the present study, we used this bioassay to investigate the possible involvement of $\mathrm{NO}$ in the uterotrophic action of oestradiol, using L-nitroarginine methyl ester (L-NAME) as an inhibitor of NO synthase (Rees et al., 1990) and immature rats as a model system (Ramalay, 1979). 


\section{Materials and Methods}

\section{Animals and treatments}

Immature female Wistar rats (19-2I days old) 25-38 g, were used. All animals were allowed free access to food and water and were maintained on a $12 \mathrm{~h}$ light:12 h dark cycle. For experimentation, they were randomly assigned to groups.

\section{Drugs}

The following drugs from Sigma Chemical Co., (St Louis, $\mathrm{MO})$ were used: oestradiol, L- $N^{\omega}$-nitroarginine methyl ester (L-NAME), L-arginine and L-lysine. Oestradiol was dissolved in corn oil and all other drugs were dissolved in sterile $0.9 \%(\mathrm{w} / \mathrm{v})$ saline. The test drugs used did not have any effect on uterine mass.

\section{Bioassay of oestrogen}

The technique described by Calhoun et al. (1971) to measure oestrogen was used. Groups of 6-10 immature female rats were administered oestradiol in a single s.c. dose of $2.5,5$ or $10 \mu \mathrm{g}$ per rat to study the uterine oedema response after $6 \mathrm{~h}$ or in repeated doses of $3 \mu \mathrm{g}$ per rat per day for three consecutive days to study the uterine growth response after $72 \mathrm{~h}$. At the end of the $6 \mathrm{~h}$ or $72 \mathrm{~h}$ period, the animals were killed by an excess of ether and the wet and dry uterine masses were obtained and expressed in $\mathrm{mg}$ per $40 \mathrm{~g}$ body mass. While assessing the influence of test drugs, the increase in uterine wet mass after $6 \mathrm{~h}$ and the increase in uterine dry weight after $72 \mathrm{~h}$ were taken as the parameters of oestradiol-induced uterine oedema and growth effects, respectively.

The test drugs, L-NAME $\left(5-20 \mathrm{mg} \mathrm{kg}^{-1}\right.$, i.p.), L-arginine and L-lysine $\left(600 \mathrm{mg} \mathrm{kg}^{-1}\right.$, s.c.) or their combinations were injected $30 \mathrm{~min}$ before to study their influence on the uterotrophic actions of oestradiol. In the study of uterine growth response to oestradiol, the test drugs were administered twice a day. Control animals received corn oil $(0.1 \mathrm{ml}$ per rat, s.c.).

\section{Statistical analyses}

The results are reported as means \pm SEM. Statistical analysis of differences between groups was performed by ANOVA and the Newman-Keuls' or Dunnett's test, with significance set at $P<0.05$.

\section{Results}

\section{Uterine oedema response to oestradiol}

At $6 \mathrm{~h}$ after oestradiol $(2.5,5$ and $10 \mu \mathrm{g}$ per rat) administration, a dose-related increase $(P<0.05)$ was observed in uterine wet mass (Fig. 1) but not in dry mass, indicating that oestradiol induces uterine oedema. Systemic administration of L-NAME (10 and $20 \mathrm{mg} \mathrm{kg}^{-1}$ ), the NO synthase inhibitor, significantly decreased the uterine wet mass increase induced by $10 \mu \mathrm{g}$ oestradiol (Fig. 2). The L-NAME (20 $\mathrm{mg} \mathrm{kg}^{-1}$ )-induced

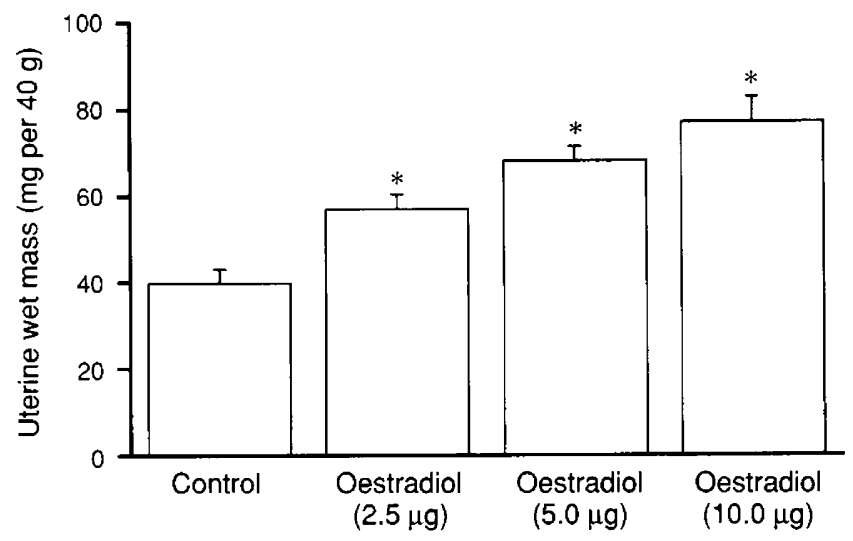

Fig. 1. The uterotrophic response to oestradiol administration after $6 \mathrm{~h}$ in immature rats. Corn oil (control) or oestradiol was given as a single s.c. injection in a volume of $0.1 \mathrm{ml}$. The animals were killed $6 \mathrm{~h}$ after oestradiol injection and the uterine masses were obtained. Values are means $\pm \operatorname{SEM}(n=6) . * P<0.05$ (versus control; Dunnett's test).

attenuation of uterine mass gain provoked by oestradiol was inhibited significantly by $600 \mathrm{mg}$ L-arginine $\mathrm{kg}^{-1}$ but not by L-lysine at a similar dose (Fig. 2).

\section{Uterine growth response to oestradiol}

In rats treated with oestradiol ( $3 \mu \mathrm{g}$ per rat) for $72 \mathrm{~h}$, the uterine wet and dry masses were significantly increased, indicating oedema inducing as well as growth promoting properties of oestradiol. These increases were significantly attenuated in animals pretreated with L-NAME (10 and $20 \mathrm{mg}$ $\left.\mathrm{kg}^{-1}\right)$. The effect of L-NAME $\left(20 \mathrm{mg} \mathrm{kg}^{-1}\right)$ was almost completely reversed by L-arginine.

\section{Discussion}

Immature rats were used to examine whether NO plays a role in the uterotrophic effects of oestradiol because, at this age, serum concentrations of oestrogen and progesterone are very low, whereas the appropriate receptors are present at adult concentrations (Ramalay, 1979; Rendt et al., 1992). Six hours after single s.c. injections of oestradiol, the oedema-inducing effect was apparent, as evidenced by a significant dosedependent enhancement in uterine wet mass but not in dry mass. The wet mass increase after oestradiol administration occurs because oestrogen enhances uterine blood flow, capillary permeability and causes oedema of the endometrial stroma in rats (Psychoyos, 1966; Phaily and Senior, 1978; Marshall and Senior, 1986).

The increase in dry mass of uteri in rats treated with oestradiol for $72 \mathrm{~h}$ represents the true growth response and is associated with cellular hypertrophy and hyperplasia of the uterus. This growth response may arise from interactions with soluble receptor proteins in the uterine tissue and subsequent stimulation of gene transcription (Clark and Peck, 1979; Parker, 1986; Halachmi et al., 1994) involving polypeptide growth factors such as IGF-I, EGF and TGF- $\alpha$ (Mukku and Stancel, 1985; Nelson et al., 1992; Sahlin et al., 1994). 


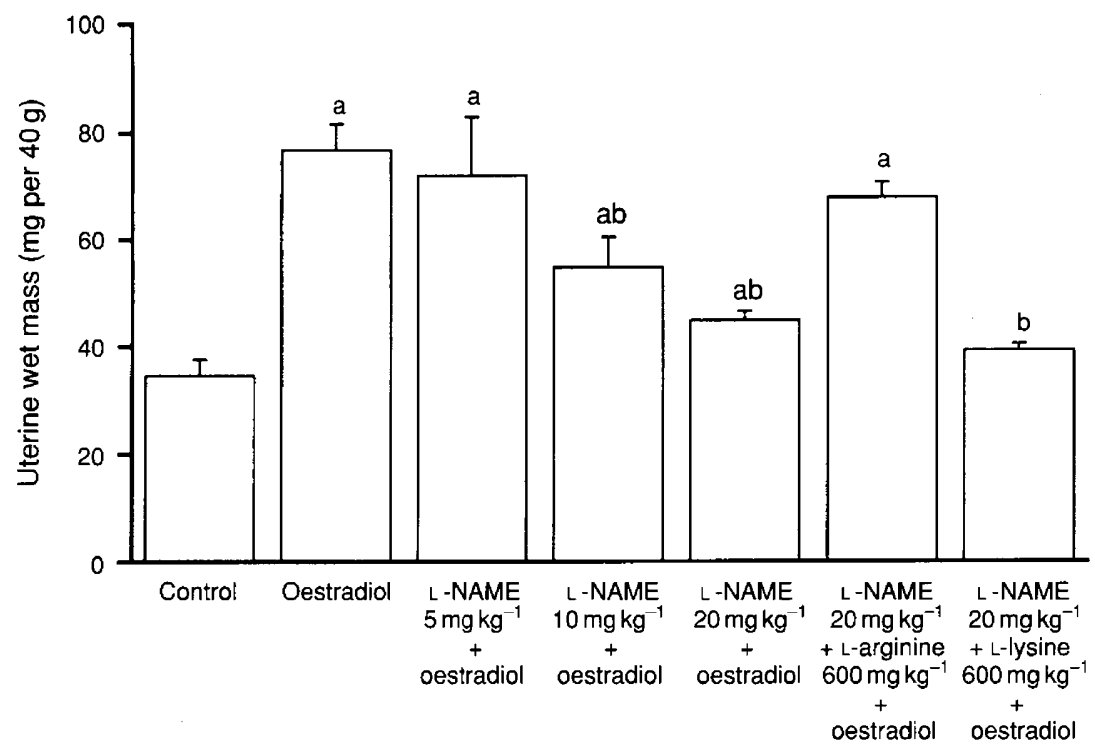

Fig. 2. The inhibitory efect of $N^{(\omega)}$-nitro-L-arginine methyl ester (L-NAME) on uterotrophic response induced by $10 \mu \mathrm{g}$ oestradiol after $6 \mathrm{~h}$ in immature rats and its reversal by L-arginine. Oestradiol was given s.c. and L-NAME i.p., $30 \mathrm{~min}$ before oestradiol. Controls received $0.1 \mathrm{ml}$ of corn oil. ' $P<0.05$ (versus control; ANOVA and Newman-Keuls' test). ${ }^{\mathrm{b}} \mathrm{P}<0.05$ (versus oestradiol alone; ANOVA and Newman-Keuls' test).

Table 1. The inhibitory effect of L-NAME on the uterotrophic response to oestradiol after $72 \mathrm{~h}$ in immature rats and its reversal by L-arginine

\begin{tabular}{|c|c|c|}
\hline \multirow[b]{2}{*}{ Treatment } & \multicolumn{2}{|c|}{ Uterine mass (mg per $40 \mathrm{~g}$ ) } \\
\hline & Wet & Dry \\
\hline Control & $50.6 \pm 4.9$ & $21.3 \pm 1.8$ \\
\hline Oestradiol $3 \mu \mathrm{g}$ per rat, s.c. on 3 successive days & $197.8 \pm 15.7^{\mathrm{a}}$ & $48.6 \pm 2.8^{\mathrm{a}}$ \\
\hline L-NAME + oestradiol $5 \mathrm{mg} \mathrm{kg}^{-1}$, i.p. twice a day for 3 days & $170.2 \pm 14.1^{\mathrm{a}}$ & $41.2 \pm 3.1^{\mathrm{a}}$ \\
\hline L-NAME + oestradiol $10 \mathrm{mg} \mathrm{kg}^{-1}$, i.p. twice a day for 3 days & $152.6 \pm 5.8^{\mathrm{ab}}$ & $38.8 \pm 3.7^{\mathrm{ab}}$ \\
\hline L-NAME + oestradiol $20 \mathrm{mg} \mathrm{kg}^{-1}$, i.p. twice a day for 3 days & $139.3 \pm 6.6^{\mathrm{ab}}$ & $34.0 \pm 2.5^{\mathrm{ab}}$ \\
\hline $\begin{array}{l}\text { L-NAME }+ \text { L-arginine }+ \text { oestradiol }\left(20 \mathrm{mg} \mathrm{kg}^{-1} \text {, i.p. }\right) \\
\left(600 \mathrm{mg} \mathrm{kg}^{-1} \text {, s.c.) twice a day for } 3 \text { days }\right.\end{array}$ & $206.0 \pm 16.6^{\mathrm{a}}$ & $46.6 \pm 5.4^{\mathrm{a}}$ \\
\hline
\end{tabular}

Values are means \pm SEM from six to ten animals. Controls received $0.1 \mathrm{ml}$ of corn oil s.c. on three successive days. The differences in uterine wet and dry masses between the control (vehicle) and drug-treated rats are considered indicative of uterine oedema and growth responses, respectively. L-NAME ( $N^{(1)}$-nitro-L-arginine methyl ester) and L-arginine were administered 30 min before oestradiol. ' $P<0.05$ (versus control, ANOVA and Newman-Keuls' test).

${ }^{b} P<0.05$ (versus oestradiol alone, ANOVA and Newman-Keuls' test).

The oestradiol-induced uterine oedema and proliferative responses were significantly attenuated in a dose-related manner by pretreatment of rats with L-NAME, an inhibitor of NO synthase that converts L-arginine to NO. It is likely that these effects of L-NAME are due to dose-related decreases in blood flow to the uterine muscle. To ensure that the effect of L-NAME was mediated only by NO, we tested L-NAME (20 $\mathrm{mg} \mathrm{kg}^{-1}$ ) in association with an excess of l-arginine (600 $\left.\mathrm{mg} \mathrm{kg}^{-1}\right)$, a precursor of $\mathrm{NO}$, or with an excess of L-lysine $\left(600 \mathrm{mg} \mathrm{kg}^{-1}\right)$, an amino acid that is not involved in NO biosynthesis. The results evidenced that an excess of L-arginine could reverse the attenuating effect of L-NAME on oestradiol-induced uterine oedema and growth. It indicates the presence of an arginine-NO system in the uterus that is stimulated by oestrogen, and that the enzyme involved is a constitutive isoform of NO synthase. The source of the NO is not clear from this study. Oestrogen may induce endotheliumdependent, as well as independent, NO through activation of NO synthase in the uterine artery endothelial cells or in the vasodilator neurones supplying the uterine artery (Van Buren et al., 1992; Morris, 1993; Shew et al., 1993; Weiner et al., 1994). In conclusion, our study suggests a role for NO in the uterotrophic action of oestrogen in immature rats.

This work was supported by National Research Council (CNPq), Brazil. 


\section{References}

Calhoun FJ, Tolson WW and Schrogie IJ (1971) Effect of various drugs on the uterotrophic response to mestranol and norethynodrel in the rat Proceedings of the Society for Experimental Biology and Medicine 136 47-50

Clark JH and Peck EJ, Jr (1979) Female sex steroids: receptors and function Endocrinology 14 1-245

Clark KE, Mills EG, Stys SJ and Seeds AE (1981) Effects of vasoactive polypeptides on the uterine vasculature American Journal of Obstetrics and Gynecology 139 182-188

Cunha GR, Chung LWK, Shannon JM, Taguchi $\mathrm{O}$ and Fujii H (1983) Hormoneinduced morphogenesis and growth: role of mesenchymal-epithelial interactions Recent Progress in Hormone Research 39 559-598

Gardner RM, Verner G, Kirkland JL and Stancel GM (1989) Regulation of uterine epidermal growth factor (EGF) receptors by estrogen in the mature rat and during the estrous cycle Joumal of Steroid Biochemistry 32 339-343

Halachmi S, Marden E, Martin G, Mackay H, Abbodanza C and Brown M (1994) Estrogen receptor-associated proteins: possible mediators of hormone-induced transcription Science 264 1455-1458

Ignarro LJ, Harbison RG, Wood KS and Kadowitz PJ (1986) Activation of purified soluble guanylate cyclase by endothelium-derived relaxing factor from intrapulmonary artery and vein in stimulation by acetylcholine, bradykinin and arachidonic acid journal of Pharmacology and Experimental Therapeutics $237893-900$

Jovanovic A, Grbovic L and Tulic I (1994) Predominant role for nitric oxide in the relaxation induced by acetylcholine in human uterine artery Human Reproduction 9 387-393

Magness RR and Rosenfeld CR (1989) Local and systemic estradiol-17 beta: effects on uterine and systemic vasodilatation American Journal of Physiology 256 E536-E542

Makowski EL (1977) Vascular physiology. In Biology of the Uterus pp 77-100 Ed. RM Winn. Plenum Press, New York

Marshall K and Senior J (1986) Ornithine decarboxylase inhibition and the uterotrophic response to oestrogen in rats Journal of Reproduction and Fertility 76 597-601

Molnar M, Suto T, Toth T and Hertelendy F (1994) Prolonged blockade of nitric oxide synthesis in gravid rats produces sustained hypertension, proteinuria, thrombocytopenia, and intrauterine growth retardation American Journal of Obstetrics and Gynecology 170 1458-1466

Moncada S, Palmer RMJ and Higgs EA (1991) Nitric oxide: physiology, pathophysiology and pharmacology Pharmacological Reviews 43 109-142

Morris JL (1993) Co-transmission from autonomic vasodilator neurons supplying the guinea pig uterine artery Journal Autonomic Nervous System $\mathbf{4 2}$ 11-22

Mukku VR and Stancel GM (1985) Receptors for epidermal growth factor in the rat uterus Endocrinology 117 149-154

Murphy LJ, Murphy LC and Freisen HG (1987) Estrogen induces insulin-like growth factor-I expression in the rat uterus Molecular Endocrinology 1 $445-450$
Myatt L, Brewer AS, Langdon G and Brockman DE (1992) Attenuation of the vasoconstrictor effects of thromboxane and endothelin by nitric oxide in the human fetal-placental circulation American Journal of Obstetrics and Gynecology 166 224-230

Nelson KG, Takahashi T, Lee DC, Luetteke NC, Bossert NL, Ross K, Eitzman BE and McLachlan JA (1992) Transforming growth factor- $\alpha$ is a potential mediator of estrogen action in the mouse uterus Endocrinology 131 1657-1664

Parker MG (1986) Mechanism of steroid hormone action Cancer Surveys 5 625-633

Phaily S and Senior J (1978) Modification of estrogen-induced hyperemia by drugs in the ovariectomized rat Journal of Reproduction and Fertility 53 91-97

Psychoyos A (1966) Study of the relations of the ovum and endometrium during delay of nidation on the first phases of the nidation process in the female rat Comptes Rendus Hebdomadaires des Séances de L'Academie des Sciences 263 D1755-D1758

Ramalay JA (1979) Development of gonadotropin regulation in the prepubertal mammal Biology of Reproduction 20 1-31

Rees DD, Palmer RMJ, Schulz R, Hodson HF and Moncada S (1990) Characterization of three inhibitors of endothelial nitric oxide synthase in vitro and in vivo British Journal of Pharmacology 101 746-752

Rendt JM, Toro L, Stefani E and Erulkar SD (1992) Progesterone increases $\mathrm{Ca}^{2+}$ currents in myometrial cells from immature and nonpregnant adult rats American Journal of Physiology 262 C293-C301

Resnik R, Killam AP, Barton MD, Battaglia FC, Makowski EL and Meschia G (1976) The effect of various vasoactive compounds upon the uterine vascular bed American Journal of Obstetrics and Gynecology 125 201-206

Sahlin L, Norstedt G and Eriksson H (1994) Estrogen regulation of the estrogen receptor and insulin-like growth factor- $I$ in the rat uterus: a potential coupling between effects of estrogen and IGF-I Steroids 59 421-430

Shew RL, Papka RE, McNeill DL and Yee JA (1993) The NADPH-diaphorasepositive nerves and the role of nitric oxide in CGRP relaxation of uterine contraction Peptides 14 637-641

Still JG and Greiss FC (1978) The effects of prostaglandins and other vasoactive substances on uterine blood flow and myometrial activity American Journal of Obstetrics and Gynecology 130 1-8

Tamaya T, Motoyama T, Ohno Y, Ide T, Tsurusaki T and Okada H (1979) Estradiol $17 \beta$, progesterone and dihydrotestosterone receptors of uterine myometrium and myoma in the human subject Journai of Steroid Biochemistry $10615-619$

VanBuren GA, Yang DS and Clark KE (1992) Estrogen-induced uterine vasodilatation is antagonized by L-nitroarginine methyl ester, an inhibitor of nitric oxide synthesis American Journal of Obstetrics and Gynecology $167828-833$

Weiner CP, Lizasoain I, Baylis SA, Knowles RG, Charles IG and Moncada S (1994) Induction of calcium-dependent nitric oxide synthases by sex hormones Proceedings of the National Academy of Sciences, USA 91 5212-5216

Yallampalli C, Izumi H, Byam-Smith M and Garfield RE (1994) An L-argininenitric oxide-cyclic guanosine monophosphate system exists in the uterus and inhibits contractility during pregnancy American Journal of Obstetrics and Gynecology 170 175-185 